\title{
Modeling acid-gas generation from boiling chloride brines
} Guoxiang Zhang*, Nicolas Spycher, Eric Sonnenthal and Carl Steefel

\author{
Address: Earth Sciences Division at Lawrence Berkeley National Laboratory, MS 90-1116, 1 Cyclotron Road, Berkeley, CA 94720, USA \\ Email: Guoxiang Zhang* - GXzhang@lbl.gov; Nicolas Spycher - NSpycher@lbl.gov; Eric Sonnenthal - ELSonnenthal@lbl.gov; \\ Carl Steefel - CISteefel@lbl.gov \\ * Corresponding author
}

Published: 16 November 2009

Geochemical Transactions 2009, 10:II doi:10.1 186/1467-4866-10-II
Received: 27 September 2008

Accepted: 16 November 2009

This article is available from: http://www.geochemicaltransactions.com/content/I0/I/I I

(C) 2009 Zhang et al; licensee BioMed Central Ltd.

This is an Open Access article distributed under the terms of the Creative Commons Attribution License (http://creativecommons.org/licenses/by/2.0), which permits unrestricted use, distribution, and reproduction in any medium, provided the original work is properly cited.

\begin{abstract}
Background: This study investigates the generation of $\mathrm{HCl}$ and other acid gases from boiling calcium chloride dominated waters at atmospheric pressure, primarily using numerical modeling. The main focus of this investigation relates to the long-term geologic disposal of nuclear waste at Yucca Mountain, Nevada, where pore waters around waste-emplacement tunnels are expected to undergo boiling and evaporative concentration as a result of the heat released by spent nuclear fuel. Processes that are modeled include boiling of highly concentrated solutions, gas transport, and gas condensation accompanied by the dissociation of acid gases, causing low-pH condensate.
\end{abstract}

Results: Simple calculations are first carried out to evaluate condensate $\mathrm{pH}$ as a function of $\mathrm{HCl}$ gas fugacity and condensed water fraction for a vapor equilibrated with saturated calcium chloride brine at $50-150^{\circ} \mathrm{C}$ and I bar. The distillation of a calcium-chloride-dominated brine is then simulated with a reactive transport model using a brine composition representative of partially evaporated calcium-rich pore waters at Yucca Mountain. Results show a significant increase in boiling temperature from evaporative concentration, as well as low $\mathrm{pH}$ in condensates, particularly for dynamic systems where partial condensation takes place, which result in enrichment of $\mathrm{HCl}$ in condensates. These results are in qualitative agreement with experimental data from other studies.

Conclusion: The combination of reactive transport with multicomponent brine chemistry to study evaporation, boiling, and the potential for acid gas generation at the proposed Yucca Mountain repository is seen as an improvement relative to previously applied simpler batch evaporation models. This approach allows the evaluation of thermal, hydrological, and chemical (THC) processes in a coupled manner, and modeling of settings much more relevant to actual field conditions than the distillation experiment considered. The actual and modeled distillation experiments do not represent expected conditions in an emplacement drift, but nevertheless illustrate the potential for acid-gas generation at moderate temperatures $\left(<150^{\circ} \mathrm{C}\right)$.

\section{Background}

This study was conducted as part of investigations related to the long-term safety assessment of the proposed highlevel nuclear waste repository at Yucca Mountain, Nevada. The heat released by the spent nuclear fuel is expected to induce boiling at near-atmospheric pressure of pore water (moisture) present in the unsaturated rock around wasteemplacement tunnels [1-5]. This boiling, as well as the deliquescence of naturally occurring salts in dust, could lead to the formation of residual brines $[6,7]$ at tempera- 
tures significantly above the boiling point of pure water [8], possibly accompanied by the release of acid gases such as $\mathrm{HCl}$ and formation of acid condensate $[9,10]$. The potential enhancement of waste package corrosion by the release of $\mathrm{HCl}$ and other acid gases from such solutions and subsequent formation of acid condensate was the primary motivation for this study.

Gaseous $\mathrm{HCl}$ is often a primary cause of well-casing and pipe-system corrosion in geothermal systems [11-13]. For this reason, many studies have focused on gaseous $\mathrm{HCl}$ and acid condensates in geothermal areas. In most instances, the $\mathrm{HCl}$ source is volcanic in origin [14-17]. Fournier and Thompson [18] reported the generation of $\mathrm{HCl}$ gas through steam-driven hydrolysis of $\mathrm{NaCl}$ at $600^{\circ} \mathrm{C}$ and pressures up to $700 \mathrm{bar}$, and suggested that the hydrolysis of chloride brines could be at the origin of $\mathrm{HCl}$ gas in volcanic and sub-volcanic environments. Bischoff et al. [19], studying the generation of $\mathrm{HCl}$ gas in the $\mathrm{CaCl}_{2}-\mathrm{H}_{2} \mathrm{O}$ system at high temperature $\left(380-500^{\circ} \mathrm{C}\right.$ and pressure (up to about $800 \mathrm{bar}$ ), showed that this system generates significant amounts of $\mathrm{HCl}$ in the vapor phase by the hydrolysis of $\mathrm{CaCl}_{2}$. These authors concluded this mechanism is likely the source of $\mathrm{HCl}$ in steam at the Geysers geothermal system in Northern California.

Very few experiments have been conducted to evaluate the formation of $\mathrm{HCl}$ gas in natural systems at atmospheric pressure and (relatively) low temperatures. In the context of geologic disposal of nuclear waste, Pulvirenti et al. [10] distilled a synthetic concentrated $\mathrm{CaCl}_{2}$-type water representative of some of the calcium-rich pore waters at Yucca Mountain. These authors observed a number of acid gases released from the concentrated brine, including $\mathrm{HCl}, \mathrm{Cl}_{2}$, $\mathrm{NO}, \mathrm{NO}_{2}$, and $\mathrm{HNO}_{3}$. The vapor from their distillation experiments produced acid condensate $(\mathrm{pH}<1)$. Olsen et al. [9] conducted experiments similar to those of Pulvirenti et al. [10], and also obtained highly acid distillate and brine boiling temperatures exceeding $140^{\circ} \mathrm{C}$. In this case, the authors suspected the acid gas produced may have consisted primarily of nitrosyl chloride (NOCl), which would be expected to release $\mathrm{HCl}$ upon contact with water [20]. In both these cases, solutions were boiled in closed or partially closed systems that were unlike the conditions in a waste emplacement drift, but nevertheless indicated the generation of acid gases at temperatures significantly lower than is characteristic of geothermal systems.

Understanding the generation of acid gases and condensates is important for protecting metal structures from corrosion in geothermal production systems (and other engineered systems in the vicinity of boiling solutions). Modeling studies can provide insights into these processes and thus can be quite helpful. For example, Helgeson [21] and Glover [22] calculated the theoretical maximum $\mathrm{HCl}$ content of a vapor phase released from boiling a deep geothermal brine in an open system. Their results show that the maximum $\mathrm{HCl}$ content, as a function of temperature and steam fraction, can reach up to $200 \mathrm{mg} / \mathrm{kg}$. Using a batch model, Andreussi et al. [23] calculated the chemical composition of the first drop of condensate that forms at dew-point temperature through expansion of superheated geothermal steam, with implications for corrosion and scaling in turbines. Their calculation considers the solution boiling-point elevation by referring the measured boiling point of $\mathrm{NaCl}$ solutions to an ionic strength that is the same as the solution being studied. More complex modeling studies on acid-gas generation and condensation from boiling chloride brines have not been conducted, at least not in the context of multiphase flow and multicomponent reactive transport, as done here. The objective of the present study is, therefore, to assess these processes as quantitatively as possible under conditions relevant to boiling systems at atmospheric pressures. This is achieved by first presenting simple bounding derivations of condensate $\mathrm{pH}$ as a function of vapor loss from a distiller (dynamic system) for a vapor initially at equilibrium with a saturated calcium chloride brine at $50-150^{\circ} \mathrm{C}$ and 1 bar. A more complex reactive transport model is then applied to simulate the distillation of a calcium-chloride-dominant brine at atmospheric pressure. Results show that acid distillates can be generated from relatively low-temperature gases $\left(<150^{\circ} \mathrm{C}\right)$, with $\mathrm{pH}$ values strongly dependent on the amount of water vapor condensing from the gas phase.

\section{Reactive Transport Model and Thermodynamic Data}

The reactive transport simulator TOUGHREACT [[24] and references therein] is used here, extended with a Pitzer activity-coefficient model based on the formulation of Harvie et al. [25] and thermodynamic data from Wolery et al. [26] (as implemented by Alai et al. [7]). For the Ca-Cl system, interactions parameters in this database were derived from [27] (Model 2 of these authors, without separate ion pairs $\mathrm{CaCl}^{+}$and $\left.\mathrm{CaCl}_{2(\mathrm{aq})}\right)$ together with solubility data for $\mathrm{CaCl}_{2}$ hydrate salts from [28] and [29]. These data reproduce reasonably well saturation concentrations from [29] for $\mathrm{CaCl}_{2}: 2 \mathrm{H}_{2} \mathrm{O}$ up to about $100^{\circ} \mathrm{C}$ [26], however somewhat underestimate saturations (by 15-20\%) at $\sim 150^{\circ} \mathrm{C}$. A later revision of this thermodynamic database [30], not available prior to the start of this study, includes data derived from [27] (Model 3 of these authors, with separate ion pairs $\mathrm{CaCl}^{+}$and $\left.\mathrm{CaCl}_{2(\mathrm{aq})}\right)$ that yield more accurate saturations at high temperatures. For $\mathrm{HCl}(\mathrm{g})$, reference thermodynamic data are taken from [31] and extrapolated to higher temperatures using SUPCRT92 
[32]. The implementation of the Pitzer model in TOUGHREACT is presented in Zhang et al. [33,34], together with comparisons of calculated activity and osmotic coefficients with measured data from the literature [e.g., [35]].

TOUGHREACT computes reactive flow and transport for multicomponent and multiphase systems. In the present case, the multiphase system includes an aqueous phase containing dissolved salts, a gaseous phase (air, water vapor, trace gases), and various solid mineral phases. Therefore, a representative geochemical system is considered, including aqueous speciation, mineral (salts) precipitation and dissolution, and gas generation and dissolution/reaction in condensate. The coupled heating, boiling, vapor phase transport and condensation are modeled in the context of nonisothermal multiphase flow and reactive geochemical transport. The boiling point elevation caused by elevated concentrations of dissolved salts is captured in the model through the lowering of the water-vapor pressure resulting from the decrease in water activity with increasing ionic strength [34]. The numerical model relies on an equation-of-state module that computes the physical properties and phase equilibrium behavior of water and saline solutions, coupled with multiphase flow and transport (advection and diffusion) in the phases involved (liquid or gas). As such, the numerical model simulates "real" evaporation and condensation as a function of temperature, pressure, and system composition, including vapor pressure lowering and PVT effects from condensation and feedback on fluid flow [36].

It should be noted that TOUGHREACT was designed to simulate multiphase flow in porous media (i.e., using Darcy's law), and therefore cannot accurately simulate flow in open conduits (i.e., flow represented with NavierStokes equation) such as would be required for the distillation simulation presented below. In this study, flow and transport processes in open conduits are approximated using a high-permeability porous-medium representation. In this respect, simulation results regarding gas flow are regarded as more qualitative than quantitative.

\section{Preliminary Analysis}

Preliminary calculations assuming pure $\mathrm{CaCl}_{2}$ solutions were carried out to investigate relationships between salt concentration, $\mathrm{HCl}$ gas fugacity ( $\cong$ partial pressure), and condensate $\mathrm{pH}$ at various temperatures. These calculations are based on analytical derivations that are applied using computed $\mathrm{HCl}$ gas fugacities and water activities. The objective is to illustrate, as simply as possible, the effect of partial condensation (vapor loss from a distiller) on condensate $\mathrm{pH}$ in a dynamic system. Note that more sophisticated numerical simulations of distillation are presented later, and do not rely on these preliminary analyses.

First, speciation computations were run to determine the $\mathrm{pH}, \mathrm{HCl}$ gas fugacity, and water activity of solutions saturated with $\mathrm{CaCl}_{2}: 2 \mathrm{H}_{2} \mathrm{O}$ (the stable solid phase in the temperature range considered) at $1 \mathrm{bar}$ and temperatures from 50 to $150^{\circ} \mathrm{C}$ (Table 1 ). The $\mathrm{pH}$ of distillate that would form from the condensation of vapors equilibrated with these solutions was then estimated using simple relationships and assuming ideal behavior, as shown below. The speciation computations were run using the Pitzer model and thermodynamic data mentioned previously. It was noted earlier that above $\sim 100^{\circ} \mathrm{C}$, these data yield salt saturations lower than reported values $(15-20 \%$ at $\sim 150^{\circ} \mathrm{C}$ ). For this reason, results should be viewed as approximate, yielding $\mathrm{HCl}$ fugacities and water activities (and consequently condensate $\mathrm{pH}$ values) that are rather overestimated than underestimated at elevated temperatures.

For a gas mixture including $\mathrm{H}_{2} \mathrm{O}$ and $\mathrm{HCl}$ gas, the molar ratio of acid-gas to water is given by

Table I: Computed chemical properties of saturated $\mathrm{CaCl}_{2}: 2 \mathrm{H}_{2} \mathrm{O}$ solutions at $50-150^{\circ} \mathrm{C}$ and $\sim$ bar.

\begin{tabular}{|c|c|c|c|c|c|c|c|}
\hline $\begin{array}{c}\text { Temperature } \\
\left({ }^{\circ} \mathrm{C}\right)\end{array}$ & $\begin{array}{c}\log \mathbf{f}_{\mathrm{HCl}} \\
(\log \text { bar) }\end{array}$ & $\mathrm{pH}^{\prime}$ & $-\log \left(\mathrm{m}_{\mathrm{H}_{+}}\right)^{2}$ & Water Activity & $\begin{array}{l}\text { Ionic Strength } \\
\text { (molal) }\end{array}$ & $\begin{array}{c}P^{0}{ }_{\text {sat }} \\
\text { (bar) }\end{array}$ & $\begin{array}{c}P_{\mathrm{H} 2 \mathrm{O}} \\
\text { (bar) }\end{array}$ \\
\hline 50 & -5.5 & 3.0 & 5.7 & 0.174 & 35 & 0.124 & 0.022 \\
\hline 75 & -4.5 & 2.9 & 5.3 & 0.189 & 36 & 0.386 & 0.073 \\
\hline 100 & -3.7 & 2.8 & 4.9 & 0.200 & 39 & 1.014 & 0.203 \\
\hline 125 & -3.0 & 2.8 & 4.5 & 0.216 & 40 & 2.322 & 0.502 \\
\hline 150 & -2.5 & 2.9 & 4.2 & 0.235 & 42 & 4.762 & 1.119 \\
\hline
\end{tabular}

\footnotetext{
' $\mathrm{pH}$ defined as $-\log \left(a_{\mathrm{H}_{+}}\right)=-\log \left(\gamma \mathrm{m}_{\mathrm{H}_{+}}\right)$, with $\gamma$ being the activity coefficient from the Pitzer model; ${ }^{2}$ Also defined as $\mathrm{pmH}$ or $\mathrm{p}[\mathrm{H}] ;{ }^{3} \mathrm{NIST}$ tables [37]; ${ }^{4}$ Equation (5)
} 


$$
n_{\mathrm{HCl}} / n_{\mathrm{H} 2 \mathrm{O}} \cong P_{\mathrm{HCl}} / P_{\mathrm{H} 2 \mathrm{O}}
$$

where $P$ and $n$ stand for pressure and number of moles respectively. Because $\mathrm{HCl}$ is highly soluble in water and $\mathrm{H}_{2} \mathrm{O}$ is highly condensable, the ratio $n_{\mathrm{HCl}} / n_{\mathrm{H} 2 \mathrm{O}}$ in the above equation can be assumed to remain essentially the same in the distillate after full (and conservative) condensation. Therefore, we can write

$$
\left(n_{\mathrm{HCl}} / n_{\mathrm{H} 2 \mathrm{O}}\right)_{\mathrm{gas}} \cong\left(n_{\mathrm{HCl}} / n_{\mathrm{H} 2 \mathrm{O}}\right)_{\text {condensate }}=m_{\mathrm{HCl}} / 55.508
$$

where $m$ stands for molality (moles $/ \mathrm{kg}_{\text {water }}$ ) in the condensate. If the $\mathrm{pH}$ of the condensate results only from $\mathrm{HCl}$ dissociation, assuming full $\mathrm{HCl}$ dissociation and neglecting activity coefficients in the condensate, then

$$
\mathrm{pH} \cong-\log _{10}\left(m_{\mathrm{HCl}}\right)
$$

Note, in this case, $\mathrm{pH}=-\log \left(\mathrm{m}_{\mathrm{H}_{+}}\right)$and is technically referred to as pmH or $\mathrm{p}[\mathrm{H}]$. Combining Equations (1), (2), and (3) then yields

$$
\mathrm{pH}=-\log _{10}\left(P_{\mathrm{HCl}}\right)-\log _{10}(55.508)+\log _{10}\left(P_{\mathrm{H} 2 \mathrm{O}}\right)
$$

$P_{\mathrm{H} 2 \mathrm{O}}$ can be expressed as a function of the water activity $a_{\mathrm{H} 2 \mathrm{O}}$ and pure water saturation pressure $P^{0}{ }_{\text {sat }}{ }^{\prime}$ thus taking into account vapor-pressure lowering due to salts:

$$
P_{\mathrm{H} 2 \mathrm{O}}=a_{\mathrm{H} 2 \mathrm{O}} P_{\mathrm{sat}}^{0}
$$

We now consider that only a fraction of $\mathrm{H}_{2} \mathrm{O}$ initially in the gas phase condenses, but that essentially all $\mathrm{HCl}$ in the gas phase partitions into the condensed phase (because of the very strong affinity of $\mathrm{HCl}$ for water). This would occur in a distiller when steam flows through a condenser with incomplete or poor heat transfer, and $\mathrm{HCl}$ is continuously scrubbed from the steam flowing above the condensate. Incomplete condensation can be expressed by multiplying $n_{\mathrm{H} 2 \mathrm{O}}$ by $(1-X)$ in Equation (1), where $X$ is defined as the (mass) fraction of uncondensed $\mathrm{H}_{2} \mathrm{O}$ (e.g., steam loss from a distiller). Introducing this variable in subsequent equations, and substituting Equation (5) into (4) then yields:

$\mathrm{pH}=-\log _{10}\left(P_{\mathrm{HCl}}\right)-\log _{10}(55.508)+\log _{10}\left[a_{\mathrm{H} 2 \mathrm{O}} P_{\text {sat }}^{0}(1-X)\right]$

Equation (6) was used to estimate condensate $\mathrm{pH}$ for vapors evolved from the $\mathrm{CaCl}_{2}$ solutions shown in Table
1. Results show condensate $\mathrm{pH}$ values below 2.5 for all cases, and dropping sharply with elevated steam loss as less water is available to dilute $\mathrm{HCl}$ scrubbed from the gas phase (Figure 1).

\section{Numerical Simulation of Distillation}

The distillation of a calcium-chloride-dominant brine was simulated based on an experiment reported by Pulvirenti et al. [10]. These authors distilled at atmospheric pressure a synthetic brine of a composition intended to represent evaporated Yucca Mountain pore water. The actual brine composition was determined by Rosenberg et al. [6] after evaporating a synthetic solution representative of certain types of calcium-rich pore waters at Yucca Mountain and concentrating that solution by a factor of 1,243 .

Although Pulvirenti et al. [10] give limited detail regarding their distillation experiment, they report sufficient information for us to reasonably reconfigure and simulate an experiment similar to theirs (Figure 2). These authors used an initial volume of 12 L of brine, which was prepared using a mixture of salts (Table 2). The brine was placed in a round-bottom flask on a heating mantle, heated up to $144^{\circ} \mathrm{C}$, and distilled until 40 to $250 \mathrm{~mL}$ of liquid remained in the flask (corresponding to concentration factors of $\sim 370,000$ and $\sim 60,000$, respectively, relative to the initial pore water used by Rosenberg et al. [6]). A water-cooled condenser was attached at the top of the flask. The distillate was collected at intervals for (instantaneous) $\mathrm{pH}$ measurement. The temperature was also monitored in both the flask and condenser. Towards the end of the distillation experiment, Pulvirenti et al. [10] report

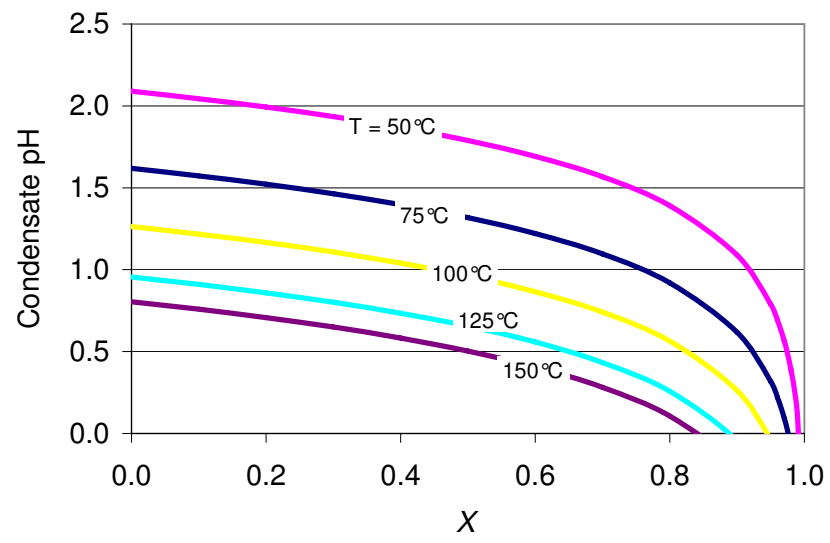

Figure I

Calculated pH (technically pmH, Equation 6) of condensates from vapors initially at equilibrium with solutions given in Table I (at temperatures shown), as a function of $\mathrm{H}_{2} \mathrm{O}$ vapor mass fraction loss from a distiller (X). $X=0$ for full $\mathrm{H}_{2} \mathrm{O}$ condensation; $X>0$ for partial condensation of a flowing vapor stream (see text). 


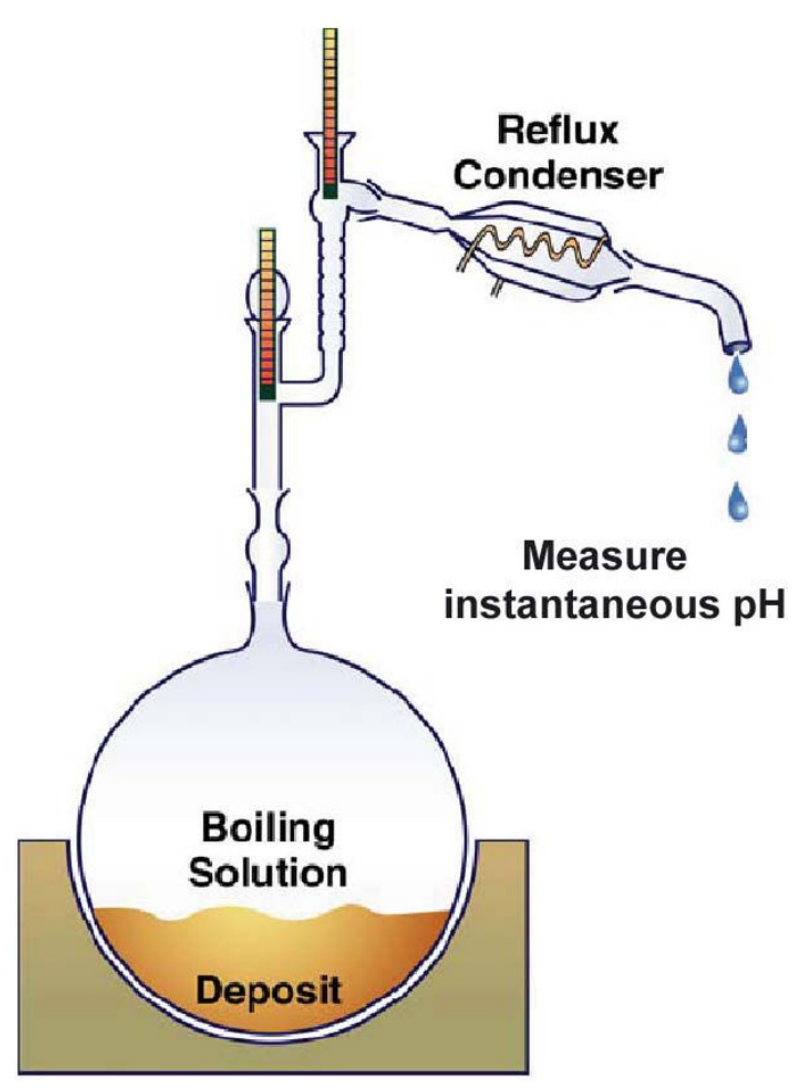

Figure 2

Schematic illustration of distillation experiment, after Pulvirenti et al. [10].

that the $\mathrm{pH}$ of the condensate droplets fell to 1 and lower. These authors also observed some solids precipitating in the boiling flask, but did not report their composition. Gases were detected using color indicator tubes and included $\mathrm{Cl}_{2}, \mathrm{NO}, \mathrm{NO}_{2}, \mathrm{HNO}_{3}$, and $\mathrm{HCl}$. Analyses of the condensate by Inductively Coupled Plasma Atomic Emission Spectrophotometry (ICP-AES) revealed the presence of large amounts of chloride and nitrate in the condensate.

To simulate this experiment, we discretized the distillation setup (Figure 2) using a number of gridblocks (Figure 3 ). Open spaces (the flask, pipe assembly, and the condenser) were represented by a high-permeability $\left(10^{-6} \mathrm{~m}^{2}\right)$ porous medium without capillarity. The gridblock representing the flask was set with a volume of $15 \mathrm{~L}$, unit porosity, and an initial liquid saturation of 0.8 to yield $12 \mathrm{~L}$ of initial solution in the flask. The liquid saturation was set to 0 everywhere else. The gridblocks representing the pipe and the condenser were set with a "porosity" of 0.64 calculated from an arbitrarily chosen pipe outer diameter of $1 \mathrm{~cm}$ and inner diameter of $0.8 \mathrm{~cm}$. The diffusion coeffi-
Table 2: Initial brine salt recipe (Pulvirenti et al. [10]).

\begin{tabular}{cc}
\hline Solute & $\begin{array}{c}\text { Concentration } \\
\text { (mg/L) }\end{array}$ \\
\hline $\mathrm{CaCl}_{2}: 2 \mathrm{H}_{2} \mathrm{O}$ & 57767 \\
\hline $\mathrm{MgSO}_{4}: 7 \mathrm{H}_{2} \mathrm{O}$ & 5382 \\
\hline $\mathrm{KNO}_{3}$ & 4205 \\
\hline $\mathrm{NaF}$ & 1198 \\
\hline $\mathrm{NaHCO}_{3}$ & 61 \\
\hline $\mathrm{SiO}_{2} \times \mathrm{H}_{2} \mathrm{O}\left(84 \% \mathrm{SiO}_{2}\right)$ & 644 \\
\hline $\mathrm{MgCl}_{2} 6 \mathrm{H}_{2} \mathrm{O}$ & 42264 \\
\hline $\mathrm{NaCl}$ & 14211 \\
\hline $\mathrm{KCl}$ & 1975 \\
\hline $\mathrm{NaOH}$ & 120 \\
\hline
\end{tabular}

cients of gases were calculated as a function of gas molecular weight and diameter, pressure, and temperature [38] with a system tortuosity assumed equal to 1 .

The atmosphere was represented using a large gridblock (essentially infinite volume) having constant temperature and pressure $\left(25^{\circ} \mathrm{C}, 1 \mathrm{bar}\right)$, and connected directly to the gridblock representing the condenser, set at the same conditions. Only the condenser gridblock was allowed contact with the atmosphere (the outlet of the condenser). Initial conditions in the gridblock representing the flask were set at the boiling point of pure water under atmospheric conditions $\left(\sim 100^{\circ} \mathrm{C}, 1\right.$ bar). Heat was applied directly to the gridblock representing the flask. No liquidphase flow was allowed to take place from the flask to the condenser; thus, mass transport resulted only from vapor flow by advection and diffusion. Heat loss by vapor flow out of the system was accounted for. Note that "real" condensation was simulated, meaning that the model relies on a full equation of state coupled to heat flow and fluid flow to predict the amount of condensation taking place by cooling in the condenser. In the present case, most of the generated vapor was predicted to flow into the atmosphere gridblock, with a minor part condensing in the condenser, as discussed later. The distillate was allowed to flow out of the condenser gridblock into the atmosphere gridblock.

The initial brine composition is shown in Table 3. This composition was calculated from the salt recipe in Table 2. The initial brine $\mathrm{pH}$ was computed from multicompo- 


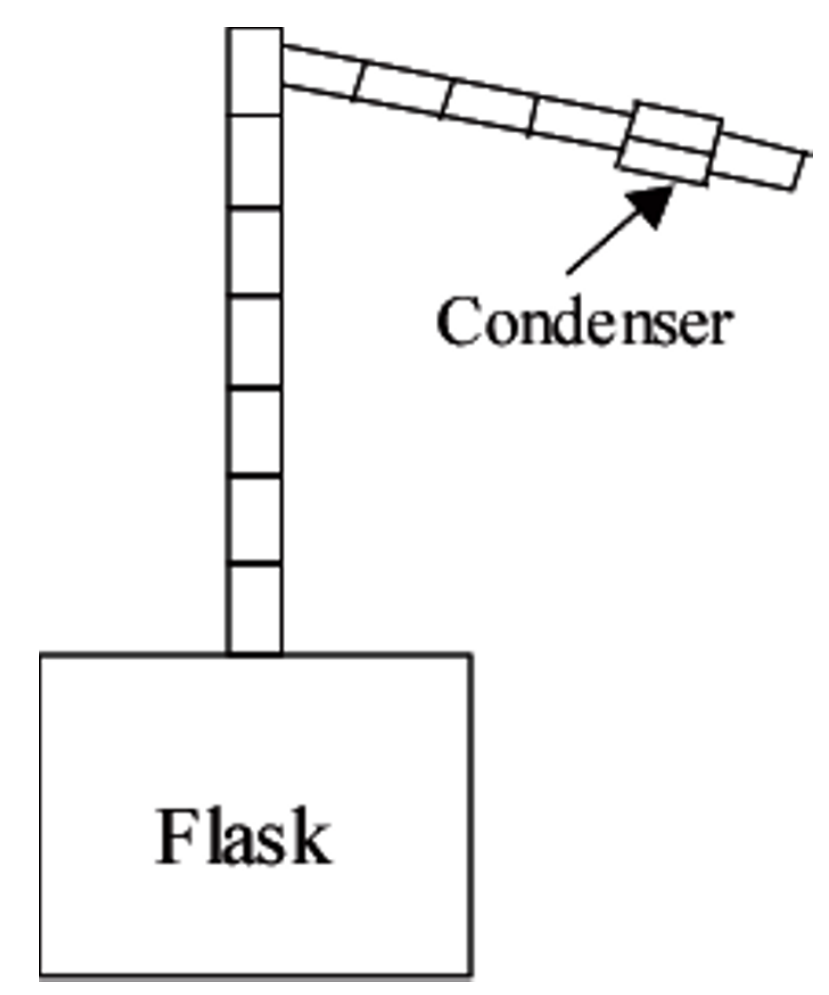

Figure 3

Discretization of the evaporation/condensation experiment simulated in this study (finite volume model). The experimental setup illustrated in Figure 2.

nent speciation using the known total (stoichiometric) hydrogen ion concentration given by the salt recipe, and assuming an initially atmospheric $\mathrm{CO}_{2}$ partial pressure. All dissolved components shown in Table 2 were considered in the simulation. In addition, a number of salts (minerals) were allowed to precipitate in the flask, including calcium chloride $\left(\mathrm{CaCl}_{2}\right.$ and $\left.\mathrm{CaCl}_{2}: 2 \mathrm{H}_{2} \mathrm{O}\right)$, calcite $\left(\mathrm{CaCO}_{3}\right)$, anhydrite $\left(\mathrm{CaSO}_{4}\right)$, niter $\left(\mathrm{KNO}_{3}\right)$, soda niter $\left(\mathrm{NaNO}_{3}\right)$, halite $(\mathrm{NaCl})$, sylvite $(\mathrm{KCl})$, epsomite $\left(\mathrm{MgSO}_{4}: 7 \mathrm{H}_{2} \mathrm{O}\right), \mathrm{Mg}\left(\mathrm{NO}_{3}\right)_{2}$, nahcolite $\left(\mathrm{NaHCO}_{3}\right)$, fluorite $\left(\mathrm{CaF}_{2}\right)$, villiaumite $(\mathrm{NaF})$, carobbite $(\mathrm{KF})$, amorphous silica $\left(\mathrm{SiO}_{2}\right)$ and magnesium chloride $\left(\mathrm{MgCl}_{2}: 4 \mathrm{H}_{2} \mathrm{O}\right)$. These salts were selected primarily on the basis of the initial salt recipe (Table 2), with added few other common minerals that could form as a result of evaporation. Note that the focus of this study was primarily on the behavior of acid gases in the vapor rather than on the exact prediction of the types and amounts of solids formed in the flask. Gases considered included $\mathrm{CO}_{2}, \mathrm{HCl}, \mathrm{HF}$, and $\mathrm{HNO}_{3}$. The initial $\mathrm{CO}_{2}$ partial pressure was assumed atmospheric everywhere, and initial partial pressures of $\mathrm{HCl}, \mathrm{HF}$, and $\mathrm{HNO}_{3}$ gases were set to reflect equilibrium with the solution in the beaker. Away from the beaker, initial partial pressures of acid gases were set to very small,
Table 3: Initial chemical composition of the synthetic brine used in the numerical simulation, determined from the salt recipe in Table 2.

\begin{tabular}{ll}
\hline Components & $\begin{array}{c}\text { Concentration } \\
(\text { molal })\end{array}$ \\
\hline $\mathrm{pH}$ & $\sim 8\left(\sim 100^{\circ} \mathrm{C}\right)^{2}$ \\
\hline $\mathrm{Ca}^{+2}$ & $4.2609 \mathrm{E}-0 \mathrm{I}$ \\
\hline $\mathrm{Cl}^{-}$ & $1.5954 \mathrm{E}+00$ \\
\hline $\mathrm{F}^{-}$ & $3.0940 \mathrm{E}-02$ \\
\hline $\mathrm{HCO}_{3}{ }^{-}$ & $7.8739 \mathrm{E}-04$ \\
\hline $\mathrm{K}^{+}$ & $7.3828 \mathrm{E}-02$ \\
\hline $\mathrm{Mg}^{+2}$ & $2.4910 \mathrm{E}-0 \mathrm{I}$ \\
\hline $\mathrm{Na}^{+}$ & $2.9866 \mathrm{E}-0 \mathrm{I}$ \\
\hline $\mathrm{SO}_{4}^{-2}$ & $2.3678 \mathrm{E}-02$ \\
\hline $\mathrm{SiO}_{2(\mathrm{aq})}$ & $1.3088 \mathrm{E}-02$ \\
\hline $\mathrm{NO}_{3}{ }^{-}$ & $4.5102 \mathrm{E}-02$ \\
\hline
\end{tabular}

I From reported initial salt concentrations in $\mathrm{mg} / \mathrm{L}$ (Table 2), assuming a solution density $\sim 1.05 \mathrm{~kg} / \mathrm{L}$. The number of significant digits is provided only for accurate numerical charge balance and does not reflect the accuracy of the data.

${ }^{2}$ Calculated by chemical speciation given input total (stoichiometric) $\mathrm{H}^{+}$concentration

essentially zero values $\left(10^{-20} \mathrm{bar}\right)$. Thermodynamic data for these phases, as well as all ion-interaction parameters for dissolved components, were taken from the sources discussed earlier. All reactions were assumed to proceed at equilibrium.

The time step size was chosen to capture the fast evaporation of the brine (relative to a constant heat input) in the final boiling stages. The simulation was run for a total boiling time of 3.1 days, a point at which the ionic strength of the brine in the flask reached 41 molal and numerical convergence was difficult to achieve. That simulation end point corresponds to a concentration factor of $\sim 54,000$ relative to initial pore water.

\section{Results}

Simulation results are presented below as a function of concentration factor (Figures 4, 5, and 6). The concentration factor can be regarded as the number by which the concentration (molality) of a conservative component in the flask would increase during the distillation process. As mentioned earlier, the starting brine in the simulation has a composition corresponding to a solution already con- 


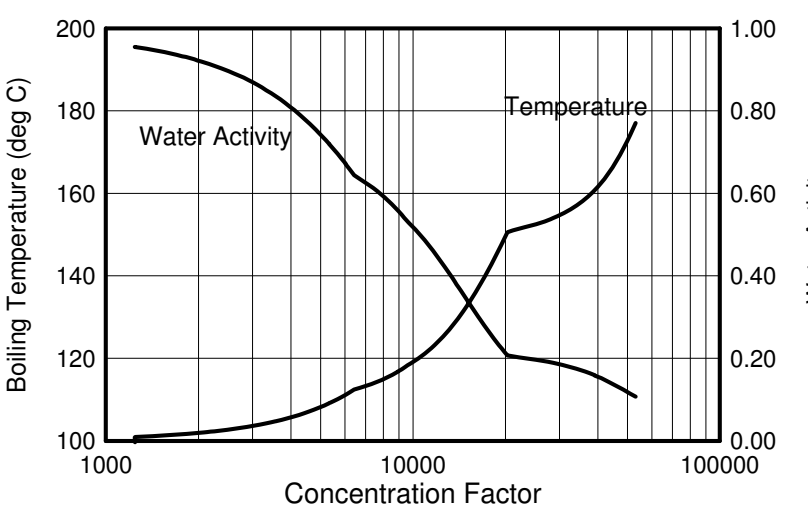

Figure 4

Simulated boiling temperature and water activity of the brine as a function of concentration factor.
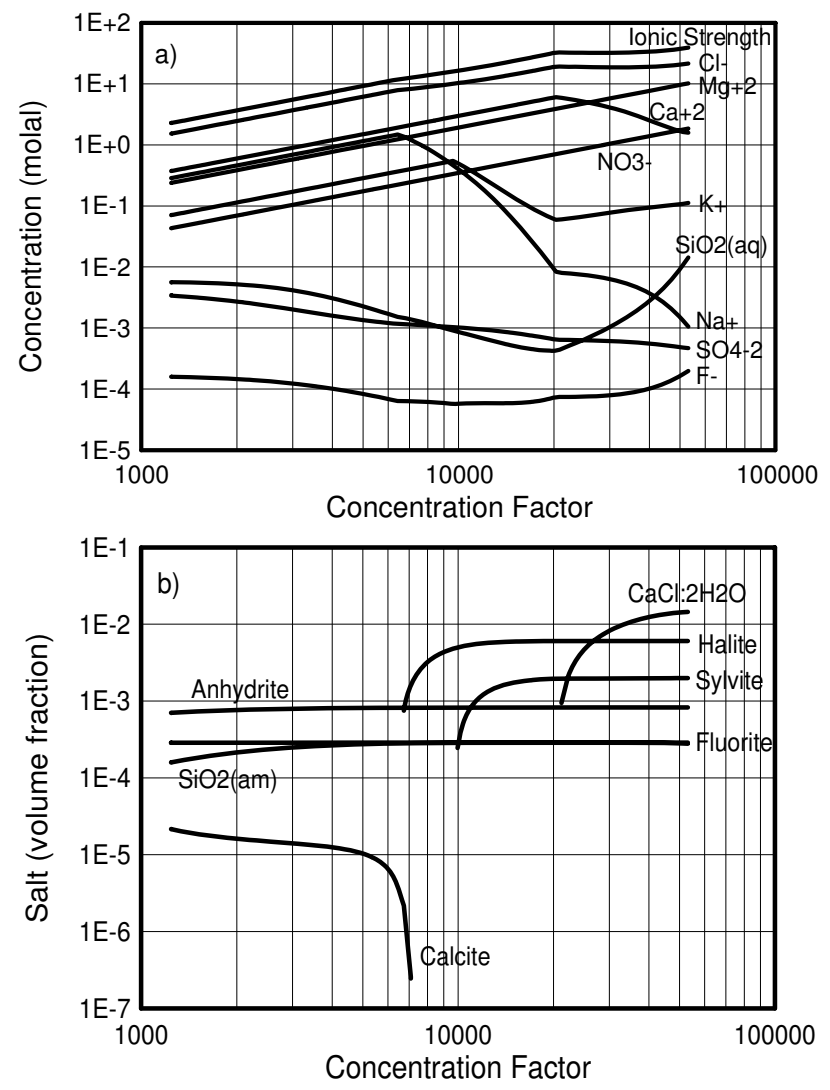

Figure 5

Simulated concentrations of aqueous components in the boiling brine (a) and predicted salt precipitation (volume fraction change) (b), as a function of concentration factor.
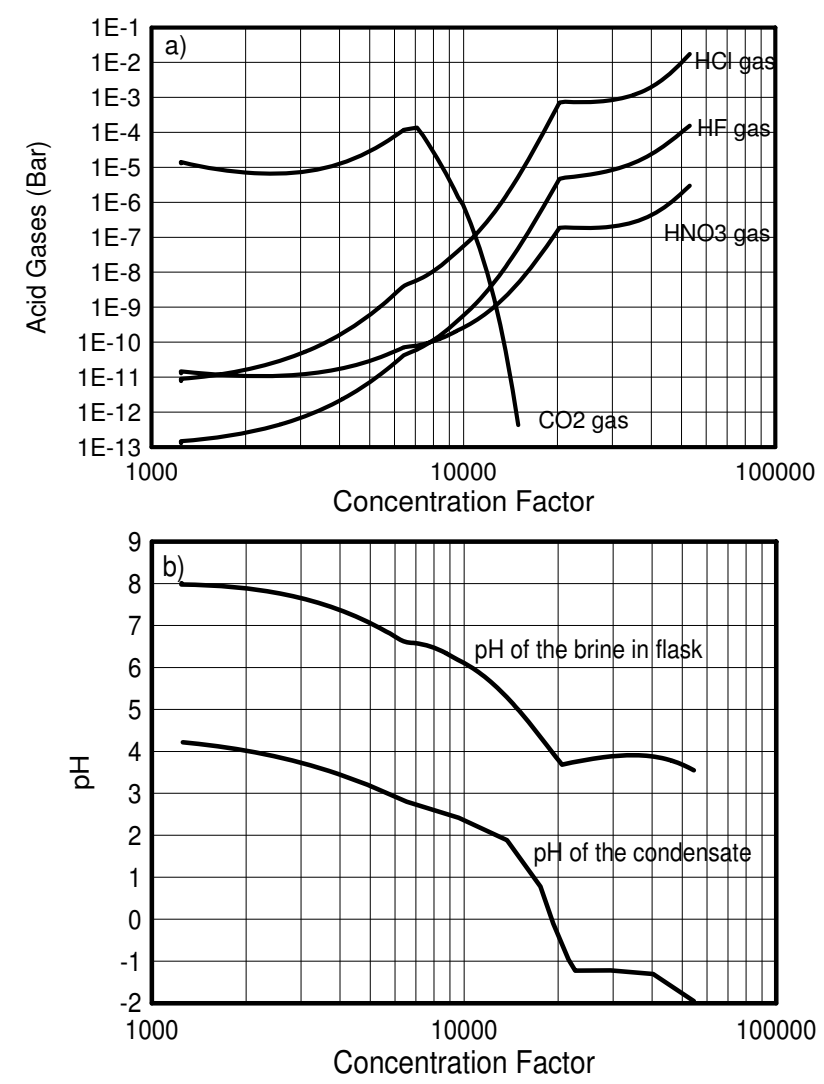

Figure 6

Simulated acid-gas partial pressures generated from the boiling brine (a), and resulting $\mathrm{pH}$ in the brine and (instantaneous) distillate after condensation at $25^{\circ} \mathrm{C}(\mathrm{b})$, as a function of concentration factor.

centrated by a factor of 1,243 relative to the initial pore water (from [6]). For this reason, the concentration factor in all figures is expressed relative to the original porewater composition (thus starting at 1,243).

The simulated temperature of the brine rises with increasing concentration factor (Figure 4), directly reflecting the effect of vapor-pressure lowering by increasing salt concentrations. Two main breaks in the temperature and water activity trends (Figure 4 ) reflect the precipitation of halite at a concentration factor around 6,500 (water activity around 0.65 ) and calcium chloride at a concentration factor of around 21,000 (water activity around 0.2) (Figure 5).

The concentrations of aqueous components increase monotonically before precipitation occurs (Figure 5). After the precipitation of halite, the sodium concentration decreases, but chloride concentration continues to 
increase, although at a decreased rate. This occurs because the chloride concentration is higher than the sodium concentration in the initial solution (Table 2). Note that the sodium concentration does not remain constant after equilibration with halite because the concentrations of other species still increase with continued boiling, thus affecting activity coefficients and the ionic activity product of halite. The same processes apply to other components. Upon further boiling, the precipitation of calcium chloride removes calcium from the solution, causing the calcium concentration to decrease and chloride concentration to nearly stabilize. Note that sylvite precipitation is predicted to start at a concentration factor close to 9,500, causing an obvious decrease in potassium concentration but essentially producing unnoticeable changes in the temperature and chloride trends. However, at the onset of calcium chloride precipitation, the potassium concentration starts to increase because the precipitation of calcium chloride consumes a lot of choride, causing sylvite to precipitate at a decreased rate. Nitrate salts were not predicted to precipitate in this simulation, which was carried out until numerical convergence was no longer achieved (at concentration factor $~ 54,000$ ).

The $\mathrm{pH}$ of the boiling brine is computed to decrease from an initial value of around 8 , with noticeable breaks at $\mathrm{pH}$ 6.6 when halite starts to precipitate (concentration factor around 6,500 ) and $\mathrm{pH}$ around 3.7 when calcium chloride forms (concentration factor around 21,000) (Figures 5 and 6). The $\mathrm{pH}$ decrease is mostly driven by the evaporative concentration effect on $\mathrm{H}^{+}$, as well as the increase in the activity coefficient of $\mathrm{H}^{+}$at higher ionic strengths, and (to a lesser extent) by the temperature effect on the dissociation of water and bicarbonate. The precipitation of halite and later calcium chloride (the two most dominant salts) are responsible for most of the reduction in the rate of ionic strength increase with evaporation (and thus most of the reduction in the rate of activity coefficient increase and water activity decrease). As a result, the precipitation of these salts coincides with breaks in the $\mathrm{pH}$ trend. Note that as a result of decreasing $\mathrm{pH}$, and a more pronounced activity coefficient increase for sulfate (double-charged) than bicarbonate (single-charged), calcite dissolves in favor of calcium sulfate precipitation (e.g., $\mathrm{SO}_{4}^{-2}+\mathrm{CaCO}_{3(\mathrm{~s})}+\mathrm{H}^{+}==>\mathrm{CaSO}_{4(\mathrm{~s})}+\mathrm{HCO}_{3}^{-}$) and eventually totally disappears at a concentration factor of about 7,200 .

Three acid gases, $\mathrm{HCl}, \mathrm{HF}$, and $\mathrm{HNO}_{3}$, are exsolved from the boiling brine in the beaker. Their partial pressure trends as a function of concentration factor (Figure 6) show breaks corresponding to the changes in $\mathrm{pH}$ discussed above (Figure 6). These breaks are indirectly induced by halite and calcium chloride precipitation (Figure 5) which also correspond to the temperature breaks observed earlier (Figure 4). The trend of $\mathrm{CO}_{2}$ partial pressure is closely related to the decreasing $\mathrm{pH}$ in the beaker (Figure 6) and the resulting dissolution of calcite (Figure 5). Initially, the $\mathrm{CO}_{2}$ partial pressure drops slightly because more $\mathrm{CO}_{2}$ is lost by gas-phase transport than produced by calcite dissolution. However, as the $\mathrm{pH}$ decreases further and more calcite dissolves, the $\mathrm{CO}_{2}$ partial pressure starts rising. Eventually, when all calcite is consumed, the $\mathrm{CO}_{2}$ partial pressure drops sharply as the brine becomes depleted in total dissolved carbonate (the diffusion of atmospheric $\mathrm{CO}_{2}$ into the distillation apparatus is not sufficient to maintain atmospheric $\mathrm{CO}_{2}$ conditions directly above the beaker).

Condensation occurs in the condenser where the vapor is cooled to $25^{\circ} \mathrm{C}$. The acid gases dissolve immediately into the condensate, causing its $\mathrm{pH}$ to drop (Figure 6). As discussed earlier, the $\mathrm{pH}$ of the condensate is controlled primarily by the fugacities of the acid gases (mostly $\mathrm{HCl}$ in this case, Figure 6) and the amount of vapor loss from the distiller. The more vapor loss (with preferential partitioning of $\mathrm{HCl}$ into the condensate), the smaller the amounts of condensed water and proportionally higher $\mathrm{HCl}$ enrichment in condensate, thus the lower the $\mathrm{pH}$ in the condensate (Figure 1). Note that in this simulation, the predicted condensate $\mathrm{pH}$ (Figure 6) represents computed values for "instantaneous" condensation (i.e., small amounts of distillate generated at prescribed intervals in time, without allowing continuous accumulation of the distillate). The condensate is allowed to accumulate for a simulated time period around 1.5 minutes. During this time, the amount of vapor flowing out of the condenser is computed to be around $96 \%$ of the $\mathrm{H}_{2} \mathrm{O}$ mass flowing into the condenser, yielding very low (negative) condensate $\mathrm{pH}$ values at elevated temperatures, in qualitative agreement with the preliminary analyses discussed earlier. When simulations are set up such that the distillate continuously accumulates in the condenser, with more complete condensation of the incoming vapor stream, predicted $\mathrm{pH}$ values in the condensate remain above 2 .

\section{Discussion and Conclusion}

Model results show low-pH condensates from acid-gas volatilization, as observed in the distillation experiments of Pulvirenti et al. [10]. When it is distilled, the synthetic concentrated brine releases acid gases, in our case predicted to consist primarily of $\mathrm{HCl}$ and HF. Two key factors, however, affect the generation of acid condensate: (1) the concentration factor and (2) the amount of condensation taking place, which is a direct function of the amount of vapor loss from the distiller (partial condensation). In our simulations, the volatilization of acid gases in quantities significant to yield condensate $\mathrm{pH}$ values below 2 were predicted only at high concentration factors (above $>20,000$ ), and only in cases where significant 
vapor loss (partial condensation) occurred. Note that Alai et al. [7] report no evidence of acid gases in evaporation experiments up to concentration factors $\sim 3,400$ using a similar type of water. This is in agreement with our results, which show that at such a lower concentration factor, the predicted partial pressures of these gases are quite low $\left(<10^{-12}\right.$ bar for $\mathrm{HF},<10^{-10}$ for $\mathrm{HCl}$, and $<10^{-11}$ for $\left.\mathrm{HNO}_{3}\right)$.

The two salts most significantly affecting predicted thermal evolution and chemical trends in the brine and vapor are halite and calcium chloride. These salts precipitate in our simulations at concentration factors of $\sim 6,500$ and $\sim 21,000$, respectively, producing noticeable breaks in the predicted trends of brine $\mathrm{pH}$ and temperature, gas partial pressures, and condensate $\mathrm{pH}$ (Figures 4, 5, and 6). These breaks occur because the rate of ionic strength increase with evaporation is sharply reduced once these minerals start to precipitate, in turn reducing the rate at which ion activity coefficients increase (and water activity decreases) with increasing evaporation. Upon continuous boiling, the most pronounced break in the trend of increasing temperatures occurs at $\sim 153^{\circ} \mathrm{C}$ when the brine becomes saturated with respect to calcium chloride. It should be noted that, upon further evaporation, predicted temperatures climbed up to near $180^{\circ} \mathrm{C}$, significantly higher than the maximum temperature $\left(\sim 144^{\circ} \mathrm{C}\right)$ in the distillation experiment [10]. Because of large uncertainties in ioninteraction parameters for mixtures of multiple salts at elevated temperature, most notably those of the nitrate salts, model results above $\sim 150^{\circ} \mathrm{C}$ (above concentration factors $\sim 20,000$ ) should be viewed with caution.

The model presented in this study incorporates physical and chemical processes affecting the boiling of saline solutions, including boiling point elevation, salt precipitation, and brine chemistry at elevated ionic strength and temperature. By implementing these processes into an existing reactive transport code, we were able to reproduce, at least semi-quantitatively, the volatilization of acid gases and generation of acid condensate observed in laboratory experiments such as those of Pulvirenti et al. [10] and Olsen et al. [9]. The simulation of vapor flow by advection and diffusion was only approximate because open conduits were approximated by a porous medium with high permeability. Nevertheless, fundamental processes were captured, including evaporative concentration with vapor-pressure lowering, volatilization of $\mathrm{HCl}, \mathrm{HF}$, and $\mathrm{HNO}_{3}$, and transport followed by dissociation of these gases into vapor condensate.

The combination of reactive transport with multicomponent brine chemistry to study evaporation, boiling, and the potential for acid gas generation at the proposed Yucca Mountain repository is seen as an improvement relative to previously applied simpler batch evaporation models
$[6,7]$. This approach allows the evaluation of thermal, hydrological, and chemical (THC) processes in a coupled manner, and modeling of settings much more relevant to actual field conditions than the distillation experiment considered here. Further modeling work by the authors [34] has integrated the type of brine distillation model presented here into full THC simulations of the near-field within and around waste emplacement tunnels. These simulations show that deleterious effects of acid gases from boiling pore waters at Yucca Mountain are not anticipated because very small amounts of acid gases are generated, that are quickly buffered by the comparatively large rock mass surrounding emplacement tunnels.

\section{Competing interests}

The authors declare that they have no competing interests.

\section{Authors' contributions}

GZ and NS carried out numerical simulations, initial draft, revisions and final compilation of the manuscript. ES and CS helped in numerical simulations and manuscript revision. All authors read and approved the final manuscript.

\section{Acknowledgements}

The authors would like to thank three anonymous reviewers for their careful and helpful reviews. We also thank John Apps for a very useful internal review of this paper, and Daniel Hawkes for editorial support. This manuscript has been authored by Lawrence Berkeley National Laboratory under Contract No. DE-AC02-05CHI I23I with the U.S. Department of Energy. The views and opinions of authors expressed in this article do not necessarily state or reflect those of the United States Government or any agency thereof or The Regents of the University of California.

\section{References}

I. Buscheck TA, Nitao J): The impact of thermal loading on repository performance at Yucca Mountain: Part I. Modeling and Analysis. Nuclear Technology 1993, 104:4I8-448.

2. Buscheck TA, Glascoe LG, Lee KH, Gansemer J, Sun Y, Mansoor K: Validation of the multiscale thermohydrologic model used for analysis of a proposed repository at Yucca Mountain. J of Contaminant Hydrology 2003, 62-63:42I-440.

3. Haukwa CB, Wu YS, Bodvarsson GS: Modeling thermal-hydrological response of the unsaturated zone at Yucca Mountain, Nevada. J of Contaminant Hydrology 2003, 62-63:552-552.

4. Spycher N, Sonnenthal E, Apps J: Fluid flow and reactive transport around potential nuclear waste emplacement tunnels at Yucca Mountain, Nevada. J of Contaminant Hydrology 2003, 6263:653-674.

5. Sonnenthal E, Ito A, Spycher N, Yui M, Apps J, Sugita Y, Conrad M, Kawakami S: Approaches to modeling coupled thermal, hydrological, and chemical processes in the Drift Scale Heater Test at Yucca Mountain. International Journal of Rock Mechanics and Mining Sciences 2005, 42:698-719.

6. Rosenberg ND, Gdowski GE, Knauss KG: Evaporative chemical evolution of natural waters at Yucca Mountain, Nevada. Applied Geochemistry 2001, I 6: 1231-1240.

7. Alai M, Sutton M, Carroll S: Evaporative evolution of $\mathbf{N a}-\mathbf{C l}-$ $\mathrm{NO}_{3}-\mathrm{K}-\mathrm{Ca}-\mathrm{Mg}-\mathrm{Si}$ brine at $95^{\circ} \mathrm{C}$ : experiments and modeling relevant to Yucca Mountain, Nevada. Geochemical Transactions 2005, 6:3I-45.

8. Carroll S, Craig L, Wolery T: Deliquescence of $\mathbf{N a C l}-\mathrm{NaNO}_{3}$, $\mathrm{KNO}_{3}-\mathrm{NaNO}_{3}$, and $\mathrm{NaCl}-\mathrm{KNO}_{3}$ salt mixtures from 90 to $120^{\circ} \mathrm{C}$. Geochemical Transactions 2005, 6:19-30. 
9. Olsen AA, Rimstidt JD: Corrosion of Yucca Mountain high-leve radioactive waste canister material. In Water-Rock Interaction, WRI- I I Edited by: Wanty RB, Seal RR. Balkema Publishers, New York; 2004: I597-1599.

10. Pulvirenti AL, Needham KM, Adel-Hadadi MA, Barkatt A, Marks CR, Gorman JA: Multiphase corrosion of engineered barrier materials. Corrosion. NACE International, March 28-April I, 2004, New Orleans 2004.

II. White DE, Truesdell AH: Geothermal reservoirs of Taiwan-an evaluation of existing data. Mining Research and Service Organization, MOEA Report 1970, 105:51-81.

12. Ellis AJ, Mahon WAJ: Chemistry and geothermal systems. Academic Press; 1977:392.

13. Truesdell AH, Haizlip JR, Armannsson H, D'Amore F: Origin and transport of chloride in superheated geothermal steam. Geothermics 1989, I 8:295-304.

14. White DE, Waring GA: Volcanic Emanations. Data of Geochemistry, USGS Prof Paper 440-K 1963:29.

15. Noguchi K, Goto T, Ueno S, Inahashi M: Geochemical investigation of the strong acid water from the bored wells in Hakone, Japan. U.N. Symposium on Geothermal Resources, Part I. Geothermics 1976, 2:56I-563.

16. Ozawa T, Kamada M, Yoshida M, Sanemasa I: Genesis of hot springs, Part I genesis of acid hot springs. Journal of Japan Geothermal Energy Assoc 1973, I0(2):. (Ser. No. 37)

17. Lawless JV, Gonzales RC: Geothermal geology and review of exploration, Biliran Island. Proceedings of 4th New Zealand Geothermal Workshop 1982:161-167. Part I

18. Fournier RO, Thompson JM: Composition of steam in the system $\mathbf{N a C l}-\mathbf{K C l}-\mathrm{H}_{2}$ O-quartz. Geochim cosmochim Acta 1993, 57:4365-4375

19. Bischoff JL, Rosenbauer JR, Fournier RO: The generationof $\mathbf{H C l}$ in the system $\mathrm{CaCl}_{2}-\mathrm{H}_{2} \mathrm{O}$ : Vapor-liquid relations from $\mathbf{3 8 0 - 5 0 0}$ ${ }^{\circ} \mathbf{C}$. Geochimica et Cosmochimica Acta 1996, 60:7-16.

20. Bekcham LJ, Fessler WA, Kise MA: Nitrosyl chloride. Chemical Reviews I95I, 48:319-396.

21. Helgeson HC: Thermodynamics of hydrothermal systems at elevated temperatures and pressures. Am J Sci 1969, 267:729-804.

22. Glover RB: Calculation of the chemistry of some geothermal environments. DSIR New Zealand, Chemistry Division Report 1982:CD 2323.

23. Andreussi P, Corsi R, Guidi M, Marini L: Theoretical prediction of physical and chemical characteristics of the "first drop" of condensate from superheated geothermal steam. Implications for corrosion and scaling in turbines. Geothermics 1994, 23:233-255

24. Xu T, Sonnenthal E, Spycher N, Pruess K: TOUGHREACT -- A simulation program for non-isothermal multiphase reactive geochemical transport in variably saturated geologic media: applications for geothermal injectivity and $\mathrm{CO2}$ geologic sequestration. Computers and Geosciences 2006, 32:।45-165.

25. Harvie $\mathrm{CE}$, Møller $\mathrm{N}$, Weare $\mathrm{JH}$ : The prediction of mineral solubilities in natural waters: the $\mathrm{Na}-\mathrm{K}-\mathrm{Mg}-\mathrm{Ca}-\mathrm{H}-\mathrm{Cl}-\mathrm{SO}$-OH$\mathrm{HCO}_{3}-\mathrm{CO}_{3}-\mathrm{CO}_{2}-\mathrm{H}_{2} \mathrm{O}$ system to high ionic strengths at $25^{\circ} \mathrm{C}$. Geochim Cosmochim Acta 1984, 48:723-75I.

26. Wolery T, Jove-Colon C, Rard J, Wijesinghe A: Pitzer database development: Description of the Pitzer geochemical thermodynamic database data0.ypf. Appendix I. In In-Drift Precipitates/Salts Model (P. Mariner) Report ANL-EBS-MD-000045 REV 02 Las Vegas, Nevada: Bechtel SAIC Company; 2004.

27. Sterner SM, Felmy AR, Oakes CS, Pitzer KS: Correlation of thermodynamic data for aqueous electrolyte solutions to very high ionic strength using INSIGHT: Vapor saturated water activity in the system $\mathrm{CaCl}_{2}-\mathrm{H}_{2} \mathrm{O}$ to $250^{\circ} \mathrm{C}$ and Solid Saturation. International Journal of Thermophysics 1998, I9(3):76 I-770.

28. Pitzer KS, Oakes CS: Thermodynamics of calcium chloride in concentrated aqueous solutions and in crystals. Journal of Chemical and Engineering Data 1994, 39(3):553-559.

29. Pitzer KS, Shi Y: Thermodynamics of calcium chloride in highly concentrated aqueous solution and in hydrated crystals. Journal of Solution Chemistry 1993, 29(2):99-105.

30. Jove-Colon C, Wolery T, Rard J, Wijesinghe A, Jareck R, Helean K: Pitzer database development: Description of the Pitzer geochemical thermodynamic database data0.ypf.R2. Appendix I. In In-Drift Precipitates/Salts Model, ANL-EBS-MD-000045 REV 03,
DOC.20070306.0037 Las Vegas, Nevada: Sandia National Laboratories; 2007.

31. Barin I, Platzki G: Thermochemical Data of Pure Substances. Two volumes 3rd edition. New York, New York: VCH Publishers; 1995

32. Johnson JW, Oelkers E, Helgeson HC: SUPCRT92: A software package for calculating the standard molal thermodynamic properties of minerals, gases, aqueous species and reactions from I to 5000 bar and 0 to $1000^{\circ} \mathrm{C}$. Comput Geosci 1992, 1 8:899-947.

33. Zhang G, Spycher N, Xu T, Sonnenthal E, Steefel C: Reactive geochemical transport modeling of concentrated aqueous solutions with TOUGHREACT----Supplement to TOUGHREACT Users' Guide for Pitzer ion-interaction model. In Lawrence Berkley National Laboratory LBNL-57873, Berkeley, California; 2006.

34. Zhang G, Spycher N, Sonnenthal E, Xu T, Steefel C: Modeling reactive multiphase flow and transport of concentrated solutions. Journal of nuclear technology 2008, I64:180-195.

35. Ananthaswarmy J, Atkinson G: Thermodynamics of concentrated electronlyte mixtures, 5. A review of the thermodynamic properties of aqueous calcium chloride in the temperature range 273.I5-373.I5 K. J Chem Eng Data 1985, 30: 120

36. Pruess K, Oldenburg C, Moridis G: TOUGH2 User's Guide. Report LBNL-4 Lawrence Berkeley National Laboratory, Berkeley, California; 1999.

37. Wagner W, Pruß A: The IAPW formulation $\mathbf{I 9 9 5}$ for the thermodynamic properties of ordinary water substance for general scientific use. Jour Phys Ref Data 2002, 3 I:387.

38. Lasaga AC: Kinetic theory in the earth sciences. Princeton University Press, Princeton, New Jersey; 1998.
Publish with Biomed Central and every scientist can read your work free of charge

"BioMed Central will be the most significant development for disseminating the results of biomedical research in our lifetime. "

Sir Paul Nurse, Cancer Research UK

Your research papers will be:

- available free of charge to the entire biomedical community

- peer reviewed and published immediately upon acceptance

- cited in PubMed and archived on PubMed Central

- yours - you keep the copyright
BiolMedcentral 